\title{
THE TREND OF YOUNG MARRIAGE ON INSTAGRAM SOCIAL MEDIA INFLUENCERS IN SHAPING YOUTH'S VIEWS
}

\author{
Novita DAMAYANTi*, Yos Horta MELIALA, and Fatihatul Sabilla SILMI \\ Prof. Dr. Moestopo (Beragama) University, Jakarta, Indonesia \\ *novita.damayanti@dsn.moestopo.ac.id
}

\begin{abstract}
The massive information on various social media platforms, particularly Instagram, frequently shows the euphoria or attractiveness of young marriages by influencers who may have privileges that may be different from the followers. This study focuses on two primary issues, namely: the background of young marriage among influencers and the youth's view on the young marriage trend among influencers. This study aims to discover the reasons of young marriages performed by influencer and learn about the youth's view on the trend of young marriage influencers on social media Instagram. This study uses the basics of mass communication, computer mediated communication theory, new media, symbolic interaction and social reality construction. This study uses a qualitative approach with case study. Data collection techniques are conducted in-depth interviews and the object of research is the content of young marriage influencers and the subjects in this study are young people and influencers. The results of the study show that influencers conducting young marriages are based on the desire to have children quickly, the freedom and the desire to learn responsibility. The youth's view on influencer young marriage constructs expectations of freedom, romance and happiness of young marriage so that many young people are encouraged to do young marriages that are motivated by influencers and the neighbors.
\end{abstract}

Keywords: Young Marriage, Influencers, Youth‘s View, Symbolic Interactions

\section{BACKGROUND}

Married at a young age, constitutionally referred to as early marriage, is a marriage performed by teenager at the age of 16 years for women while 19 years for men that is based on Marriage Law No. 1 of 1974. The ideal age limit for marriage as reported by Irianto (2015) in (Haniyfa et al., 2019) is 21 to 25 years for women and 25 to 28 years for men. At that ideal age, women reproductive organs are considered to develop properly, strong and mature and physically ready to be a mother. Men at that age are considered to be strong psychologically and physically to support family life. Biologically, the reproductive organs are not ready to have sex in marriages under the age of 19 and it can cause prolonged psychological trauma in the child. Moreover, the risk of stunting may occur in the child born because the nutrition that should be needed by the mother who is still in her teens or growing period must be divided in half to the child he had conceived.

However, Indonesia has a low number to categorize the ideal age, referring to the Marriage Age Maturation Program and the Research and Development Center of the National Population and Family Planning Agency (BKKBN, 2017) which mentions the recommendation to marry at the age of 21 years for women and 25 years for men. Meanwhile, according to IPPF (2007) (International Parenthood Planned Federation), young marriage is defined as marriage before the child reaches the age of 18 years, before the child is physically, physiologically and psychologically mature to be responsible for the marriage and the children from the marriage.

Nowadays, the problem of early marriage is a world problem. According to UNICEF data (2016), more than 700 million women married at the early age, even 3 of the women were married before 15 years. The 2014 BKKBN data in Guilbert 2013 on Satriandari \& Utami (2019: 106) shows that the total of teenagers in Indonesia has reached
74 million people, which $59 \%$ of 15 to 19 years are married (Satriandari \& Utami, 2019). Central Statistics Agency (BPS) stated that 44 percent of women in Indonesia are married at the age 19 to 24 years old (young age). However, 11.21 percent of married women are under the age of 15 years. Furthermore, 23.03 percent are married at 17 to 18 years old, and 13.07 percent are over 25 years old.

According to Cahyono 2016 in (Halim et al., 2020), social media has influenced social life in society. Changes in social relations and all forms of changes in social institutions in a society affect the social system, including values, attitudes, and behavior patterns among groups in society. Well-known people who have an existence on social media can be categorized to be influencers. According to Hariyanti $\&$ Wirapraja, an influencer is a public figure in social media who has significant number of followers, and their daily life can influence the behavior of the followers (Aulia, 2019). The development of social media content increases more influencers, so that currently influencers are divided into two, namely micro and macro influencers. Based on Whello.id, micro influencers are social media users who have 1,000 to 100,000 followers, while macro influencers are social media users who have more than 100,000 followers to 1,000,000 people or even more (Pramudyatama, 2021).

Influencers are aggressively post moments of young marriage on the Instagram because of the great influence on social media,. The most discussed cases of young influencers are Alvin Faiz (17 years old) - Larissa Chou (20 years old) in 2016, Salmafina (18 years old) - Taqy Malik (20 years old) in 2019, Tegar Septian (18 years old) - Sarah Sheilka (23 years old), and Rey Mbayang (21 years old) - Dinda Hauw (23 years old). At the end of 2020, social media was shocked by both cases of Tegar Septian and Rey Mbayang.

The engagements of influencers through campaign or simply share moments of young marriage have finally 
shaped a lot of perceptions among young people without the support of the educational element. Based on Databoks from Napoleoncat.com, the 18 to 24 year age group is the dominant age as media users. Instagram has 19 percent, the rest of users are from the 25 to 34 year age group by 15.9 percent (Napoleoncat, 2021). Meanwhile, according to the World Health Organization reported by the Indonesian Ministry of Health, the age limit for adolescents is the population with an age range of 10 to 19 years. According to the Regulation of the Minister of Health of the Republic of Indonesia No. 25 of 2014, adolescents are residents with an age range of 10 to 18 years, while the age range of adolescents from the BKKBN is 10 to 24 years and is not married (Ministry of Health of the Republic of Indonesia, 2021).

Based on the data through the Instagram insight of young married influencers Sarah and Tegar, it shows teenagers followers on 18 to 24 years old as 50.4 percent and 40.6 percent are dominated by 18 to 24 age groups. This influencer couple also had an engagement of 2.01 percent on Sarah's Instagram and 2.17 percent on Tegar's Instagram (BLADE, 2021).

Social media marks an impact on teenage users where teenagers are easily influenced by media (Agianto et al., 2020). Thus, teenagers are likely to be influenced by information about influencer young marriage information on social media.

Based on the existence of a reality through social media to form a youths' view of young marriage, this research tries to explain the conditions between the trend of young marriage by influencers through social media and the emergence of certain views on adolescents by using the theory of social reality construction proposed by Berger \& Luckman in (Luzzar, 2015). Construction of Social Reality is a social process through actions and interactions between individuals or groups of individuals. The condition creates a reality that is owned and experienced subjectively and continuously. Furthermore, Berger \& Luckman explained that as creators of objective social reality, humans have simultaneously adopted three dialectical moments, namely: Externalization, Objectivation and Internalization. Based on the background, this research was conducted to find out the reasons for young influencer marriages and youth's views on influencer marriage.

\section{METHOD}

The research approach of this study is a qualitative approach. Nasution (1992:12) in Rukajat (2018) suggests that qualitative research observes people in their environment and interaction by trying to understand the language and interpretation of the world around them (Rukajat, 2018: 1). Thus, this research involves the process of observing influencers and youth from the views on young marriage.

In understanding the research theme, the researcher interviewed the informants by asking several questions, and the informants could construct meaning to the situation. Generally, the information is description of words. The data can be interpreted to reveal the results of research in a narrative manner. In this study, the object of research is the young marriage content of influencers and the subjects in this study are young people and influencers. The method used is a case study to discuss a single case broadly.

The purpose of the interview was conducted by researchers to obtain answers to questions on a research topic. The aim was to achieve research results that focus on the views of young marriage from teenagers and the reasons for influencer marriage.

\section{RESULTS AND DISCUSSION Results}

his study has six young people as key informants that are consist of three male and three female and influencer couple. The informants in this study were Afrila\#1, Aliya\#2, Adinda\#3, Ilham\#4, Nugi\#5 and Adit\#6. Influencer couple informants are Sarah and Tegar\#7. These following descriptions are the profiles of each informant:

Afrila as the first informant is a 21-year-old student from Medan. She is the third grade student at Vocational High school Prayatna Medan. Afrila was born and raised in Medan. He is the third child of three siblings. In her neighborhood, there is no young marriage. Afrila's Instagram account is@afrila_nadyqa who has been a follower of Sarah and Tegar for about two years.

Aliya as the second informant is 14 year old student from Serang, Banten. Aliya is the first grade student at Junior High School no 1 Serang. Aliya was born and raised in Serang with parent and two younger siblings. She is the eldest of three children. In the neighborhood, many people do young marriages. Aliya's Instagram account is @aliyakamilaaa_.Aliya has been a follower of Sarah and Tegar for approximately 1.5 years.

Adinda as the third informant is 23-year-old girl who has graduated from Vocational High school and she is working. Adinda was born and raised in Jakarta with parents and two siblings. In the environment, many people conduct young marriages. She is the third child of three siblings. Adinda's Instagram account is @tiaradindaaa and has been a follower of Tegar for three years and Sarah for one year.

Ilham as the fourth informant is a 20 year old teenage boy. Currently, Ilham is studying at the Immigration Polytechnic. Ilham was born and raised in Sukabumi with his mother, brother and sister. He is the second child of three siblings. In the neighborhood, young marriage is considered normal. Ilham's account is @ilhamkhomaidi and has been a follower of Tegar for two years, while being a follower of Sarah since one year ago.

Nugi is the fifth informant and he is 18 years old student from Jakarta. Nugi is the third grade student at 
Vocational High school Cikini. He was born and raised in Jakarta with parents and two older brothers and many of his neighbors are married at the young age. He is the last child of three siblings. Nugi’s Instagram account called @ shickshiqsan_and has been a follower of Sarah and Tegar for about one year.

Adit is the sixth informant who is a 21-year-old boy. He is currently studying at Diponogoro State University, Semarang. He was born and raised in Jakarta. In the neighborhood, no one is getting married at the young age. Adit's Instagram account is @adiyaksa and has been a follower of Tegar for three years and Sarah for one year.

Sarah and Tegar are married couple informants of young influencers. Tegar Septian is an Indonesian musician who went viral because of buskers and has been successful as musicians in their famous song, "I used to be who I am now". Tegar Septian went viral again after his young marriage with Sarah Sheilka. At that time, Tegar was 23 years old and Sarah was 18 years old. This young couple is also an active macro influencer on Instagram and YouTube. Sarah's Instagram account name is @ sarahsheilka and has 109 thousand Instagram followers in May 2021. Tegar's account is @tegar_official and has 342 thousand followers in May 2021. Both of them also received verified marks on their respective Instagram social media accounts.

Sarah and Tegar use Instagram as a medium to share life's moments as well as to reminisce the moments. Many moments have been shared by both of them, including courtship moments to the young marriage into content on Instagram social media.

The content often shows the romantic relationship through posts on feeds or Instagram stories. The content shows the intimacy of their relationship by displaying acts from hugging to kissing. It is not only photos, but Sarah and Tegar also often post videos on the romance of the household.

The contents of the marriage often get a lot of likes and comments from their followers. The moment is including the wedding moments, togetherness to their young wedding anniversary moments, etc. The intimate scenes often get pros and cons in the comments of the photos.

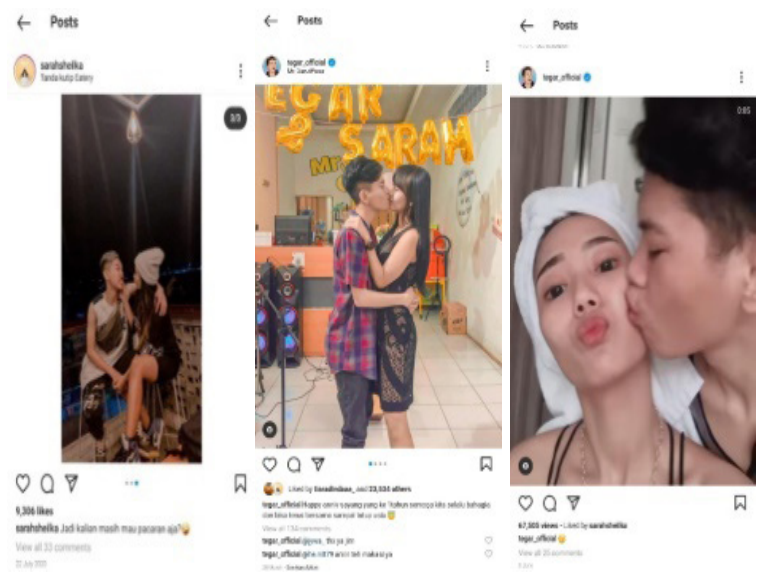

Picture 1. The content of the Influencer by Sarah and Tegar

\section{Discussion}

Young Instagram followers of Sarah and Tegar interpret young marriage differently depending on the understanding of young marriage itself. The existence of a reality through social media constructs a youth's view of young marriage. The researcher tries to explain the conditions on the relation of the trend of young marriages by influencers through social media and the emergence of certain views on teenagers through three processes of social reality construction.

In the first stage, namely externalization, young people comprehend young marriages through content on social media in the form of intimacy and romance. The good moment is reflected from many activities with a partner freely that shows the happiness of togetherness. Furthermore, in this objectivities stage, the expectations about getting married at young age appear because teenagers think that the expectations will be fulfilled if they marry at the young age. It leads to the last stage in this process of Internalization. The expectations and desires arise in marrying at the young age, then the results of young marriages portrait on influencers change the reality of teenagers on young marriage. In the reality, getting married is not only a beautiful moment but it is also considered as something fun.

The reality of young marriage is ultimately interpreted by teenagers where in the context of symbolic interaction is explained that social life is human interaction by using symbols (Ahmadi, 2008). Basically, communication is an exchange of symbols to show the meaning to communicate with each other (Ambar, 2017).

In the symbolic interactions, influencers in Instagram use symbols in the form of photos and words that present the image to the public especially to the followers. The intension of the influencer will also be interpreted by the followers, including the influence of the interpretation. Based on this situation, people share meaning in the communication process form of symbols in the form of words or pictures. Teenagers are still very determined by desire on their behavior without well perceptive of the real reality of marriage. However, the condition of the community is also a consideration in determining the behavior and decision.

This meaning process involves several stages, namely mind, self and society. These three concepts underlie the process of interpreting young marriage through symbolic interactions in conducting this research.

Mind

In this process, researchers focus on followers or teenagers who consume and view content by influencers in the form of images or photos with intimate scenes: kisses or hugs repeatedly. The content is in informal language and it is easy to understand by the social media community. The captions use supporting emoticons such as heart emoticons that describe intimacy and teenagers digesting the content into their minds. 


\section{Self-concept}

The second process in interpreting young marriage involves self or self-concept. The self-concept was developed because of the interaction between followers and influencers that provided a motive for behavior.

After the "mind" process, teenagers have their own thought to follow interesting content. They will think on the respond to young marriage content by influencers Sarah and Tegar. The urge to get married is due to the engagement through social media content with young influencers. In the concept of " $i$ " on symbolic interaction, teenagers are encouraged to do young marriages because of influencer content on social media about young marriages. In the other hand, the concept of "me" will direct the youth to act. The urge to marry in the young age in the self-process will direct and control the behavior. Thus, the behavior depends on the individual's reflective personality, especially teenagers as the subject of this research.

\section{Society}

The next process of meaning is through the Society. Person's behavior is also influenced by culture and human social processes with society. Norms also greatly influence them in interpreting things to make a decision. In this process, young people reflect on environmental conditions respond to young marriage. In the context, society is a family environment and neighborhood. In this process, teenagers tend to consider young marriages from the environment. The environment encourages teenagers to do young marriages. Thus, the role of parents is also crucial in order to give their children advice regarding marriage.

The social construction process of young marriage on social media is finally interpreted by teenagers through the stages of symbolic interaction. This research identifies that four of six teenagers are encouraged to marry young. The motivation for young marriage of a teenager is motivated by several things:

\section{Young couple influencers on social media}

Young couple influencers' moments of intimacy on social media construct a separate view for teenagers on young marriage. The moment on influencers Sarah and Tegar tends to show something that is just fun. Thus, teenagers are not able to capture the bad side of young marriage and only capture the reality by influencers through social media.

Teenagers look at the content continuously and the mind respond to the content and then decide to do natural thing as portrait in the social media. The perception is happened due to social interaction with other people, namely influencers through social media Instagram. Although each influencer on social media has different engagement and influence, the researchers identify the influencers with celebrity background on social media who have a tendency to get more influence.
The researchers found that the moments of young marriages by influencers were able to determine expectations of young marriage in teenagers. Based on the interview, the expectations of teenagers were the desire to do activities with partner. The content of romance is also a motivation of the teenagers. Adolescents also want to have a closed age from the children later. In fact, the actual married life requires a lot of consideration and preparation.

\section{Encouragement of young marriage due to the influence of the social environment}

In this study, researchers found that culture and social groups were the motivation behind young marriages. Many teenagers normalized young marriage nowadays for various reasons, mainly because of the association that tends to be free at this time.

The factor of the practice of young marriage in the family situation is also the reason for young marriage. The support for young marriage from the circle of friends greatly affects the interpretation of young marriage in adolescents and the encouragement of young marriage.

\section{Conclusion}

Based on the research entitled The Trend of Young Marriage on Instagram Social Media Influencers in Shaping Youth's Views (Case Study of Influencers Sarah and Tegar), the main reason of young marriages by influencers is due to the desire to obtain children quickly, to gain freedom and also to learn responsibility. Researchers also found that the expectations of influencers Sarah and Tegar in marrying young were to gain freedom. Meanwhile, the new media interaction through social media affects teenagers' views of young marriages by influencers on Instagram social media because the content by influencers increases expectations of young marriage. The expectations consist of freedom, happiness, and romance. The expectation of young marriages in influencers finally motivates for young marriages. Social environmental factors are also crucial factor both in the family environment and in the circle of friends. Influencers on social media have a massive power through the romantic content although influencers show things on the surface.

\section{ACKNOWLEDGMENT}

This research does not represent any interest and this research is carried out at own expense.

\section{REFERENCES}

Agianto, R., Setiawan, A., \& Firmansyah, R. (2020). The Influence of Instagram Social Media on Teenage Lifestyle and Ethics. "Pengaruh Media Sosial Instagram Terhadap Gaya Hidup dan Etika Remaja”. Tematik, 7(2). 130-139

Ahmadi, D. (2008). An Introduction to Symbolic Interaction. "Interaksi Simbolik: Suatu Pengantar". Mediator, 9(2), 301-316 
Ambar. (2017). Symbolic Interaction Theory: Concepts, Assumptions and Criticism. "Teori Interaksi Simbolik: Konsep, Asumsi dan Kritik". https:// pakarkomuniasi.com/teori-interaksi-simbolik

Aulia, A. C. (2019). Influencer as Content Creator. "Influencer Sebagai Content Creator". https:// binus.ac.id/malang/2019/01/influencer-sebagaicontent-creator/

Badan Pusat Statistik, \& Kementerian PPN/Bappenas. (2016). Child Marriage Report. https://www.unicef. org

BKKBN. (2017). Ideal Marriage on Age 21-25 Years. "Usia Penikahan Ideal 21-25 Tahun”. Bkkbn. Go.Id. https://www.bkkbn.go.id/detailpost/bkkbnusia-pernikahan-ideal-21-25-tahun

BLADE, I. (2021). Instagram Engagement. IGBLADE. igblade.com

Halim, F., Sheryl, \& Sudirman, A. (2020). Marketing and Social Media. "Marketing dan Sosial Media”. CV. Media Sains Indonesia. Bandung

Haniyfa, R., Nurfajar, A., Shihab, A., Tarumanegara, F., Rizki, M., \& Maulana, M. (2019). A Study on the Phenomenon of Young Marriage in Kayumas, Arjasa, Situbondo Regency. "Studi Terhadap Fenomena Nikah Muda di Desa Kayumas, Kecamatan Arjasa, Kabupaten Situbondo”. KSM Eka Prasetya UI, 1(8). 1-13
IPPF. (2007). Ending Child Marriage: a Guide for Global Policy Action. Ippf.Org. www.ippf.org

Irianto. (2015). Understanding Various Diseases: Causes, Symptoms, Transmission, Treatment, Recovery and Solution. "Memahami Berbagai Macam Penyakit: Penyebab, Gejala, Penularan, Pengobatan, Pemulihan dan Pengecahan”. CV. Alfabeta. Bandung

Kementrian Kesehatan RI. (2021). Adolescent Reproductive Health Situation. "Situasi Kesehatan Reproduksi Remaja”. Pusdatin.Kemkes.go.id.

Napoleoncat. (2021). Instagram Users By Gender and Age Group (May 2021). "Pengguna Instagram Berdasarkan Jenis Kelamin dan Kelompok Usia (Mei 2021)". databoks.com

Pramudyatama, Y. (2021.). Definition and Types of Influencer Marketing. "Pengertian dan Jenis-Jenis Influencer Marketing”. Whello.Id

Rukajat, A. (2018). Qualitative Research Approach. "Pendekatan Penelitian Kualitatif". CV. Budi Utama. Yogyakarta

Satriandari, Y., \& Utami, F. (2019). The phenomenon of cultural shift with the trend of early marriage in Sleman, D.I Yogyakarta. "Fenomena Pergeseran Budaya Dengan Trend Pernikahan Dini Di Kabupaten Sleman D.I Yogyakarta”. Kebidanan, 8(2), 105-114. 